\title{
Antibacterial Properties of Cymbopogon martinii essential Oil against Bacillus subtillis food industry pathogen $^{+}$
}

\author{
Sara Santamarta ${ }^{1}$, A. Cristina Aldavero ${ }^{1}$ and M. Ángeles Rojo ${ }^{2^{*}}$ \\ 1 Area of Enseñanzas Técnicas, Miguel de Cervantes European University, 47012 Valladolid. Spain; \\ sarasmorago@gmail.com (S.S.); caldavero@uemc.es (A.C.A.) \\ 2 Area of Experimental Sciences, Miguel de Cervantes European University, 47012 Valladolid. Spain; \\ marojo@uemc.es (M.A.R.) \\ * Correspondence: marojo@uemc.es \\ † Presented at the 1st International Electronic Conference on Microbiology, 2-30 November 2020; Available \\ online: https://ecm2020.sciforum.net/
}

Published: 2 November 2020

\begin{abstract}
Essential oils have great potential in the field of food industry as they effectively prevent the presence of several bacterial and fungal pathogens. Essential oils are complex volatile compounds, synthesized naturally in different plant parts during the process of secondary metabolism. The main goal of this work was to perform a qualitative evaluation antibacterial properties of 24 chemotyped essential oils against the growth of Bacillus subtillis. This gram positive bacteria is responsible for "rope" disease in bread preservation processes. The study was carried out using disk-diffusion in agar method. Biological activity was observed in five essential oils from Cymbopogon Martinii var. motia, Thymus vulgaris QT Linanol, Thymus satureioides, Mentha piperita and Eugenia caryophyllus. The first three have in common the presence of some mono terpenic derivatives such as Geraniol, Linalool and Carvacrol respectively with strong antimicrobial effect. The Cymbopogon Martinii essential oil, is one of the botanicals with the highest geraniol content (up to $80,53 \%$ ), showed more activity antimicrobial than the others. A contributing role of this knowledge could be the design of Cymbopogon Martinii essential oil formula, can be used in bakery industry as preservative, such as nano-encapsulation for bakery doughs, active packaging of baked products or surface disinfectants.
\end{abstract}

Keywords: Essential oils; Bacillus subtillis; Cymbopogon Martini; antibacterial activity; geraniol; bakery industry

\section{Introduction}

Essential oils (EO) are aromatic and volatile liquids extracted from plants material, such as flowers, aerial parts, roots, bark, leaves and fruits (Burt, 2004). The chemical composition of EOs is complex, one of them, there may have around of 20-60 different bioactive components, and only two or three are the major components at concentration within range to $20-70 \%$; the others are in traces. These composition of EOs from a one species of plant can differ from the geographic location, the hardvesting seasons or extraction method [1,2].

EOs are secondary metabolites formed by plants, their main role is to protect them against conditions of biotic and abiotic stress. They constitute about $1 \%$ of plant secondary metabolites and are mainly represented by terpenoids, phenylpropanoids or benzenoids, fatty acid derivatives and amino acid derivatives [3].

The mechanisms of antimicrobial action of EOs is mediated by a series of biochemical reactions, it is dependent on the type on chemical constituents [4]. Although the exact mechanism of 
bacteriostatic or bactericidal activity and antimicrobial effects of EOs are not exactly known, they are known to cause structural and functional damage to the membrane of bacteria by various antimicrobial mechanisms or alteration of proton pump [5-9].

The EOs are used in food industry for food preservation, due to aroma, flavors and natural antimicrobial contents against pathogenic bacteria [10-12]. Although the mechanism of action of not known in greatdetail, is necessary considerer the large number of different groups of chemical compounds present in EOs, it is most likely that their antibacterial activity is not attributable to one specific mechanism, as that there are several targets in the cell [13].

Cymbopogon Martinii var. motia, Thymus vulgaris QT Linanol, Thymus satureioides, Mentha piperita and Eugenia caryophyllus, are used traditionally as food additives [14-16]. These properties have been attributed to EO contained in the species, as well as the presence of non-volatile compounds including polyphenols and flavonoid [11]. The aim of this study was to evaluate the effect of essential oils on growth, spore production of Bacillus subtillis that could alternative synthetic chemical preservatives in bakery industry.

\section{Materials and methods}

\subsection{Bacterial strains and media.}

The Bacillus subtillis (Ehrenberg 1835) Cohn 1872, strain CECT 4522 was used in this study. B. subtillis was maintained on Nutrient Broth medium and solidified. Growth temperature was $30^{\circ} \mathrm{C}$ and the incubation time was $48 \mathrm{~h}$. Nutrient Broth medium (Beef extract, $0,5 \%$; Peptone, $1 \% ; \mathrm{NaCl}$, $0,5 \%)$ was adjust $\mathrm{pH}$ to 7.2 .

\subsection{Essential oils (EO)}

Essential oils chemotyped are extracted from different plants by steam distillation (Pranarôm, S.A.). The twenty four EO used for the study are: Citrus sinensis, Citrus reticulata, Elettaria cardamomum, Laurus nobilis, Cymbopogon martinii var.motia, Zingiber officinale, Eugenia caryophyllus, Cinnamomum camphora, Rosmarinus officinalis, Melaleuca quinquenervia, Chamaemelum nobile, Melaleuca alternifolia, Thymus vulgaris CT LINALOL, Citrus paradisi, Citrus junos, Origanum compactum, Mentha x piperita, Myrtus communis, Curcuma longa, Cinnamomum cassia, Thymus satureioides, Eucalyptus radiata ssp radiata, Cinnamosma fragrans and Mentha arvensis.

\subsection{Antibacterial activities of essential oils}

The assessment of the antibacterial activities of essential oils was performed by the diffusion method. The disc absorption capacity was $5 \mu \mathrm{l} /$ disc only the disk diffusion assay with EOs was conducted to detect antimicrobial activity. Sterile disks were impregnated with $5 \mathrm{ul}$ of EO at different concentrations by serially diluted in vegetal oil; $(100 \%, 10 \%, 1 \%)(\mathrm{V} / \mathrm{V}))$, and each disk was placed on a Nutrient Broth Agar plate smeared with B. subtillis. The plates were incubated for $48 \mathrm{~h}$ at $30{ }^{\circ} \mathrm{C}$ to determine the antimicrobial effect. Antibacterial activity was determined by measuring the inhibition zone diameter $(\mathrm{mm})$ against each EOs (Table 1). Each reported was realized in two different experiments. As sterile vegetal oil without EO was used as a negative control.

\section{Results and Discussion}

EOs and their constituents play a key role in exerting antimicrobial activity, the result of screening of twenty-four EOs (Table 1S) was evaluated against B. subtillis.

The inhibition of EOs was show as inhibition diameter against the bacterial grow (Table 1), while the control with vegetal oil does not affect the growth of bacteria. When we compared the inhibition results at different dilution, the most of the EOs used without any dilution of the commercial EO shown a zone of inhibition. In 21 of the 24 oils tested it is observed that the inhibition zone was reduced at less oil concentration, thus dose-dependent response was clear for each essential oil. The 
citrus EOs used have not shown activity against B. subtillis; except for citrus junos, which showed activity.

We are going to focus our attention on the five oils that showed the highest antimicrobial activity at higher concentrations: Cymbopogon Martinii var. motia (palmarosa oil), Thymus vulgaris QT Linanol (thymus oil), Thymus satureioides (moroccan thyme oil), Mentha piperita (peppermint oil) and Eugenia caryophyllus (clove oil).

Essential oil of Cymbopogon Martinii var. motia exhibited potent antibacterial activity among all the essential oils tested. Although, EO of Mentha x piperita and Thymus satureioides had more moderate activity but are more effective at lower doses.

About EO of Eugenia caryophyllus and Thymus vulgaris CT LINALOL, showed no activity at higher dilution (100\%), similar to Cymbopogon Martinii var. motia. But unlike the latter EO they were less effective

Table 1. Antibacterial activity of Essential oils.

\begin{tabular}{|c|c|c|c|}
\hline \multirow[t]{2}{*}{ Essential Oil } & \multicolumn{3}{|c|}{ Inhibition zone of EO concentration (en $\mathrm{mm}$ ) } \\
\hline & $100 \%$ & $10 \%$ & $0,1 \%$ \\
\hline Origanum compactum & $2 \mathrm{~mm}$ & $0 . \mathrm{mm}$ & $0 \mathrm{~mm}$ \\
\hline Cymbopogon matinii var.motia & $8 \mathrm{~mm}$ & $0.5 \mathrm{~mm}$ & $0 \mathrm{~mm}$ \\
\hline Eugenia caryophyllus & $3 \mathrm{~mm}$ & $0.2 \mathrm{~mm}$ & $0 \mathrm{~mm}$ \\
\hline Mentha arvensis & $3 \mathrm{~mm}$ & $0.2 \mathrm{~mm}$ & $0 \mathrm{~mm}$ \\
\hline Mentha x piperita & $4 \mathrm{~mm}$ & $0.6 \mathrm{~mm}$ & $0.2 \mathrm{~mm}$ \\
\hline Thymus vulgaris CT Linanol & $4 \mathrm{~mm}$ & $1 \mathrm{~mm}$ & $0 \mathrm{~mm}$ \\
\hline Thymus satureioides & $3 \mathrm{~mm}$ & $0.2 \mathrm{~mm}$ & $0.2 \mathrm{~mm}$ \\
\hline Chamaemelum nobile & $2 \mathrm{~mm}$ & $0 \mathrm{~mm}$ & $0 \mathrm{~mm}$ \\
\hline Citrus sinensis & $0 \mathrm{~mm}$ & $0 \mathrm{~mm}$ & $0 \mathrm{~mm}$ \\
\hline Citrus reticula & $0 \mathrm{~mm}$ & $0 \mathrm{~mm}$ & $0 \mathrm{~mm}$ \\
\hline Elettaria cardamomum & $2 \mathrm{~mm}$ & $0.5 \mathrm{~mm}$ & $0.2 \mathrm{~mm}$ \\
\hline Laurus nobilis & $1 \mathrm{~mm}$ & $0.2 \mathrm{~mm}$ & $0 \mathrm{~mm}$ \\
\hline Zingiber officinale & $0.5 \mathrm{~mm}$ & $0 \mathrm{~mm}$ & $0 \mathrm{~mm}$ \\
\hline Cinnamomum camphora & $1 \mathrm{~mm}$ & $0.2 \mathrm{~mm}$ & $0 \mathrm{~mm}$ \\
\hline Rosmarinus officinalis & $0.5 \mathrm{~mm}$ & $0 \mathrm{~mm}$ & $0 \mathrm{~mm}$ \\
\hline Melaleuca quinquenervia & $1 \mathrm{~mm}$ & $0.5 \mathrm{~mm}$ & $0 \mathrm{~mm}$ \\
\hline Melaleuca alternofolia & $0.5 \mathrm{~mm}$ & $0.2 \mathrm{~mm}$ & $0 \mathrm{~mm}$ \\
\hline Citrus paradisi & $0 \mathrm{~mm}$ & $0 \mathrm{~mm}$ & $0 \mathrm{~mm}$ \\
\hline Citrus junos & $1 \mathrm{~mm}$ & $0.5 \mathrm{~mm}$ & $0 \mathrm{~mm}$ \\
\hline Myrtus communis & $0.5 \mathrm{~mm}$ & $0 \mathrm{~mm}$ & $0 \mathrm{~mm}$ \\
\hline Curcuma longa & $1 \mathrm{~mm}$ & $0.5 \mathrm{~mm}$ & $0.2 \mathrm{~mm}$ \\
\hline Cinnamomum cassia & $0.5 \mathrm{~mm}$ & $0.2 \mathrm{~mm}$ & $0 \mathrm{~mm}$ \\
\hline Eucalyptus radiata ssp radiata & $2 \mathrm{~mm}$ & $0.8 \mathrm{~mm}$ & $0 \mathrm{~mm}$ \\
\hline Cinnamosma fragrans & $0.5 \mathrm{~mm}$ & $0 \mathrm{~mm}$ & $0 \mathrm{~mm}$ \\
\hline
\end{tabular}

The biological activity of EOs depend of composition of volatile principles such as terpernes, terpenoids, phenol-derived aromatic components and aliphatic components. They represent a natural source of bioactive compounds. At table 1S, we can see some the terpenic derivatives and phenylpropanoids more representatives present on the EOs analyzed. Carvacol and thymol is present in Thymus satureioides, eugenol is found in Eugenia caryophyllus, geraniol and linalool is present in Cymbopogon matinii var.motia, the limonene in Mentha x piperita and linalol in Thymus vulgaris CT Linanol. Others authors have also shown the antibacterial activity of these monoterpenes present in EO and their use in food industry $[17,18]$. Besides, it is important to consider the synergism potential of several volatile components in this effect antimicrobial [10]. The synergistic of EOs with various nanocarriers plays an emerging role in the food industry [19]. Development of techniques such as 
microencapsulation has the ability to enhance the oxidative stability, thermostability, shelf-life, and biological activity of oils [20].

Recent studies reveal the antibacterial activity of different EOs applied in bakery products including thyme, cinnamon, oregano, and lemongrass, that can inhibit the growth of harmful microorganisms, resulting in a product with extended shelf-life and enhanced safety [21]. Essential oil extracted from Cymbopogon martini showed the highest activity against both gram positive and gram-negative bacteria among the tested essential oils [22]. B. subtillis, a gram-positive bacterium, is responsible for "rope" disease in bread preservation processes [23, 24]. The use of palmarosa oil could be considered to avoid this presence of rope in bread.

At the same time, palmarosa essential oil as antioxidants in food play an important role as a health protecting factor. They are high reactive against free radicals and oxygen species from a wide variety of sources in biological systems [25].

\section{Conclusion}

The results obtained in this study confirm the antibacterial and antioxidant activities of five essential oils: Cymbopogon Martinii var. motia, Thymus vulgaris QT Linanol, Thymus satureioides, Mentha piperita and Eugenia caryophyllus. All of them contain compounds with antioxidant activity (phenolic compounds), that may be used to prevent the growth of bacteria by damaging their membrane.

In food industry, the products must be supplied without any microbial contamination. The possible use of EOs to increase the shell life and safety of bakery products, raises new technological solutions despite some limitations, such as altered sensory parameters, may limit its applications.

Development of techniques such as nano-encapsulation for bakery doughs, active packaging of baked products or surface disinfectants is required. A choice to introduce Cymbopogon Martinii essential oil formula in bakery industry. However, further research is needed to evaluate the safety and the effectiveness of this EO in bakery doughs.

Supplementary Materials: The following are available online at http://www.xxxxx, Table S1: Chemical components from the essential oils.

Author Contributions: conceptualization, S.S., A.C.A. and M.A.R; methodology, S.S. and M.A.R.; writingoriginal draft preparation, S.S., A.C.A. and M.A.R.; writing-review and editing, A.C.A. and M.A.R.

Funding: This research received no external funding

Acknowledgments: The authors would like to thank the availability of Alfredo Quevedo Fernandez and Francesca Falzone from Pranarôm (Spain) for providing information and the analysis sheet of the essentials oils.

Conflicts of Interest: The authors declare no conflict of interest

\section{References}

1. Arumugam, G; Swamy, MK; Sinniah, U.R. Plectranthus amboinicus (Lour.) Spreng: Botanical, Phytochemical, Pharmacological and Nutritional Significance. Molecules. 2016, 21, 369. DOI:10.3390/molecules21040369.

2. Malti, C.E.W.; Boussaïd, M.; Belyagoubi, L.; Paoli, M.; Gibernau, M.; Tomi, F.; Atik Bekkara, F.; Bekhechi, C. Chemical Variability of the Essential Oil of Pituranthos scoparius from Algeria. Chem Biodivers. 2018, 15, e1800149. DOI: 10.1002/cbdv.201800149.

3. Dudareva, N.; Negre, F.; Nagegowda, D.; Orlova, I. Plant Volatiles: Recent Advances and Future Perspectives. Crit. Rev. Plant Sci. 2006, 25, 417 - 440. DOI: 10.1080/07352680600899973.

4. Nazzaro, F.; Fratianni, F.; De Martino, L.; Coppola, R.; De Feo V. Effect of essential oils on pathogenic bacteria. Pharmaceuticals (Basel). 2013, 6, 1451-1474. DOI:10.3390/ph6121451.

5. Burt, S. A.; Der Zee, R. V.; Koets, A. P.; De Graaff, A. M., Van Knapen, F.; Gaastra W.; Haagsman, H. P.; Veldhuizen, E. J. Carvacrol induces heat shock protein 60 and inhibits synthesis of flagellin in Escherichia coli O157:H7. Appl. Environ. Microbiol. 2007, 73, 4484-4490. DOI:10.1128/AEM.00340-07. 
6. Cox, S.D.; Mann, C.M.; Markham, J.L.; Bell, H.C.; Gustafson, J.E.; Warmington, J.R.; Wyllie, S.G. The mode of antimicrobial action of essential oil of Melaleuca alternifolia (tea tree oil). J. Appl. Microbiol. 2000, 88, 170-175. DOI: 10.1046/j.1365-2672.2000.00943.x.

7. Swamy, M.K.; Akhtar, M.S.; Sinniah, U.R. Antimicrobial Properties of Plant Essential Oils against Human Pathogens and Their Mode of Action: An Updated Review. Evidence-based complementary and alternative medicine: eCAM. 2016; 2016: 3012462. DOI: 10.1155/2016/3012462.

8. Kloucek, P.; Smid, J.; Frankova, A.; Kokoska, L.; Valterova, I.; Pavela, R. Fast screening method for assessment of antimicrobial activity of essential oils in vapor phase. Food Research International. 2012, 47, 161-165. DOI: 10.1016/j.foodres.2011.04.044.

9. Trombetta, D.; Castelli, F.; Sarpietro, M.G.; Venuti, V.; Cristani, M.; Daniele, C.; Saija, A.; Mazzanti, G.; Bisignano, G. Mechanisms of Antibacterial Action of Three Monoterpenes. Antimicrob Agents Chemother. 2005, 49, 2474-2478. DOI:10.1128/AAC.49.6.2474-2478.2005.

10. Bhavaniramya, S.; Vishnupriya, S.; Al-Aboody, M.; Vijayakumar, R.; Baskarana, D. Role of essential oils in food safety: Antimicrobial and antioxidant applications. Grain and Oil Sci. and Technol. 2019, 2, 49-55. DOI: 10.1016/j.gaost.2019.03.001.

11. Chouhan, S.; Sharma, K.; Guleria, S. Antimicrobial Activity of Some Essential Oils-Present Status and Future Perspectives. Medicines (Basel). 2017, 4, 58. DOI:10.3390/medicines4030058.

12. Djenane, D.; Aïder, M.; Yangüela, J.; Idir, L.; Gómez, D.; Roncalés, P. Antioxidant and antibacterial effects of Lavandula and Mentha essential oils in minced beef inoculated with E. coli O157:H7 and S. aureus during storage at abuse refrigeration temperature. Meat Sci. 2012, 92, 667-74. DOI: 10.1016/j.meatsci.2012.06.019.

13. Burt, S. Essential oils: their antibacterial properties and potential applications in foods--a review. Int J Food Microbiol. 2004, 94, 223-53. DOI: 10.1016/j.ijfoodmicro.2004.03.022.

14. Fahimi, S.; Hajimehdipoor, H.; Shabanpoor, H; Bagheri, F.; Shekarchi, M. Synergic antibacterial activity of some essential oils from Lamiaceae. Research J. Pharmacogn. 2015, 2, 23-29.

15. Promila, P. A review on the medicinal and aromatic Plant- Cymbopogon martinii (Roxb.) Watson (Palmarosa) Promila. 2018, 6.,1311-1315.

16. Yoshida, P.A.; Yokota, D.; Foglio, M.A.; Rodrigues, R.A.; Pinho, S.C. Liposomes incorporating essential oil of Brazilian cherry (Eugenia uniflora L.): characterization of aqueous dispersions and lyophilized formulations. J Microencapsul. 2010, 27, 416-25. DOI: 10.3109/02652040903367327.

17. Laranjo, M.; Fernández-Léon, A.M.; Potes, M.E.; Agulheiro-Santos, A.C.; Elias, M. Use of essential oils in food preservation. In A. Méndez-Vilas (Ed.), Antimicrobial research: Novel bioknowledge and educational programs. Badajoz, Spain: Formatex Research Center, 2017; pp. 177-188.

18. Mihai, A.L.; Popa,M.E. Inhibitory effects of essential oils with potential to be used in food industry. Scientific Bulletin. Series F. Biotechnologies, 2014, 18, 220-225.

19. Kaliamurthi, S.; Selvaraj, G.; Gu, K.; Wei, D. Synergism of essential oils with nanocarriers: emerging trends in preservation of grains and related food products. Grain Oil Science Technol. 2019, 2, 21-26.

20. Bakry, A.M.; Abbas, S.; Ali, B.; Majeed, H.; Abouelwafa, M.Y.; Mousa, A.; Liang, L. Microencapsulation of Oils: A Comprehensive Review of Benefits, Techniques, and Applications. Compr. Rev. Food Sci. Food Saf. 2016, 15. 143-182. DOI: 10.1111/1541-4337.12179

21. Gavahian, M.; Chu, Y.H.; Lorenzo, J.M.; Mousavi Khaneghah, K.; Barba, F.rancisco. Essential oils as natural preservatives for bakery products: Understanding the mechanisms of action, recent findings, and applications. Crit. Rev. Food Sci.Nutr. 2020, 60, 310-321. DOI: 10.1080/10408398.2018.1525601

22. Lodhia, M. H.; Bhatt, K. R.; Thaker, V. S. Antibacterial activity of essential oils from palmarosa, evening primrose, lavender and tuberose. Indian J Pharm Sci. 2009, 71, 134-136. DOI:10.4103/0250-474X.54278.

23. Thompson, J.M.; Waites, W.; Dodd, C. Detection of rope spoilage in bread caused by Bacillus species. J. Appl Microbiol. 2002, 85, 481-486. DOI:10.1046/j.1365-2672.1998.853512.x

24. Mantzourani, I.; Plessas, S.; Saxami, G.; Alexopoulos, A.; Galanis, A.; Bezirtzoglou, E. Study of kefir grains application in sourdough bread regarding rope spoilage caused by Bacillus spp. Food Chem. 2014, 143, 1721. DOI: 10.1016/j.foodchem.2013.07.098.

25. Lawrence, K.; Lawrence, R.; Parihar, D.; Srivastava, R.; Charan, A. Anioxidant activity of palmarosa essential oil (Cymbopogon martini) grown in north indian plains. Asian Pac. J. Trop. Dis. 2012, 2, S765S768. DOI:10.1016/S2222-1808(12)60261-8. 
Publisher's Note: MDPI stays neutral with regard to jurisdictional claims in published maps and institutional affiliations.

(C) 2020 by the authors. Submitted for possible open access publication under the terms and conditions of the Creative Commons Attribution (CC BY) license (http://creativecommons.org/licenses/by/4.0/). 
Table S1. Chemical components from the essential oils. The table show the essential oils analyzed, part of the plant subjected to steam distillation and percentage of some chemical components of selected essential oil (Date obtained from analysis sheet of Pranarôm).

\begin{tabular}{|c|c|c|}
\hline Essential oil & $\begin{array}{l}\text { Part subjected to } \\
\text { steam distillation }\end{array}$ & $\begin{array}{c}\text { Chemical components of selected essential } \\
\text { oil constituents (\%) }\end{array}$ \\
\hline $\begin{array}{l}\text { Origanum } \\
\text { compactum }\end{array}$ & Flowery peak. & $\begin{array}{c}\text { Carvacrol (57.6\%); Thymol (8.21\%); } \\
\text { y-Terpineno }(14.1 \%)\end{array}$ \\
\hline $\begin{array}{c}\text { Cymbopogon matinii } \\
\text { var.motia }\end{array}$ & Aerial part. & $\begin{array}{c}\text { Geraniol (80.5\%); Geranyl acetate (8.95\%); } \\
\text { linalool (2.45\%); } \beta \text {-caryophyllene (1.87\%) }\end{array}$ \\
\hline Eugenia caryophyllus & Flower bud. & $\begin{array}{c}\text { Eugenol (79.9\%); Eugenyl acetate (12.3\%); } \beta \text { - } \\
\text { caryophyllene }(5.39 \%)\end{array}$ \\
\hline Mentha arvensis & Aerial part. & $\begin{array}{l}\text { Menthol (71.1\%); Mentone (5.88\%); } \\
\text { Isomentone (3.85\%); limonene (2.52) }\end{array}$ \\
\hline Mentha $x$ piperita & Aerial part. & $\begin{array}{c}\text { Menthol (44.5\%); Mentone (18.2\%); } \\
\text { 1,8 cineole }(4.64 \%)\end{array}$ \\
\hline $\begin{array}{c}\text { Thymus vulgaris CT } \\
\text { Linalol }\end{array}$ & Flowery peak. & $\begin{array}{c}\text { Linalool (68.4\%); Linalyl acetate }(6.19 \%) ; \beta- \\
\text { myrcene }(3.32 \%)\end{array}$ \\
\hline Thymus satureioides & Flowery peak. & $\begin{array}{c}\text { Borneol (33.4\%); Thymol (10.6\%); Carvacrol } \\
\text { (7.85\%); } \beta \text {-caryophyllene }(5.82 \%)\end{array}$ \\
\hline Chamaemelum nobile & Flower. & $\begin{array}{c}\text { Methylamine angelate }(20.2 \%) \\
\text { Metalyl angelate }(15.4 \%) \\
\text { Hexil isobutyrate }(8.31 \%)\end{array}$ \\
\hline Citrus sinensis & Shell. & Limonene $(95.3 \%)$ \\
\hline Citrus reticulata & Shell. & Limonene (71.1\%); y-Terpineno (18.3\%) \\
\hline $\begin{array}{l}\text { Elettaria } \\
\text { cardamomum }\end{array}$ & Fruit. & $\begin{array}{c}\text { Terpenyl acetate }(35.3 \%) ; 1,8 \text { Cineole }(32.3 \%) ; \\
\text { Linalyl acetate }(5.35 \%) ; \\
\text { Linalool }(3.35 \%)\end{array}$ \\
\hline Laurus nobilis & Leaves. & $\begin{array}{c}\text { 1,8 cineole }(44.9 \%) \text {; Terpenyl acetate }(10.5 \%) ; \\
\text { Sabinene }(8.86 \%) ; \\
\text { Linanool }(4.43 \%)\end{array}$ \\
\hline Zingiber officinale & Rhyzomes. & $\begin{array}{c}\alpha \text {-zingibereno }(28.2 \%) ; \alpha \text {-Curcumin }(7.93 \%) ; \\
\text { Camphene }(7.9 \%) ; \\
\beta \text {-sesquifelandrene }(7.56 \%)\end{array}$ \\
\hline $\begin{array}{l}\text { Cinnamomum } \\
\text { camphora }\end{array}$ & Leaves. & $\begin{array}{c}\text { 1,8-cineole } 56.8 \% \text {; Sabinene }(13.4 \%) \\
\alpha \text {-terpineol }(7.33 \%)\end{array}$ \\
\hline $\begin{array}{l}\text { Rosmarinus } \\
\text { officinalis }\end{array}$ & Flowery peak. & $\begin{array}{c}\alpha \text {-Pinene }(38.8 \%) \text {; Canfeno }(8.88 \%) \text {; Camphor } \\
(6.96 \%) \text {; Bornyle acetate }(6.94 \%)\end{array}$ \\
\hline $\begin{array}{l}\text { Melaleuca } \\
\text { quinquenervia }\end{array}$ & Flowery peak. & $\begin{array}{c}\text { 1,8-cineole (50.6\%); } \alpha \text {-terpineole }(8.91 \%) ; \\
\text { Limonene }(7.48 \%)\end{array}$ \\
\hline $\begin{array}{l}\text { Melaleuca } \\
\text { alternofolia }\end{array}$ & Leave. & Terpinene 4-ol (40.6\%); y-terpinene (21\%) \\
\hline Citrus paradisi & Shell. & Limonene $(94.5 \%)$ \\
\hline Citrus junos & Shell. & $\begin{array}{c}\text { Limonene (75.6\%); } \text {-terpinene }(8.49 \%) ; \\
\beta \text {-felandreno }(3.29 \%)\end{array}$ \\
\hline
\end{tabular}

